\title{
SOBRE A POSSESSÃO ERÓTICO-LÍRICA OU A PALAVRA SILÊNCIO NA POESIA DE ANTÓNIO FRANCO ALEXANDRE
}

\author{
Paulo Ricardo Braz de Sousa \\ (Universidade Federal Fluminense)
}

\section{RESUMO}

A obra do poeta português António Franco Alexandre vem despertando em seus leitores as mais variadas impressões. $O$ interesse pela recepção, contudo, é dos temas abordados pela crítica com uma recorrência constante. Neste ensaio, busca-se discutir como o erotismo é articulado ao fazer poético deste autor, tendo em vista os efeitos provocados pelas construções de sentido a partir de uma perspectiva focada nas problematizações da interlocução obra/leitor, e como a ideia do mutismo vem se coadunar a tal análise, de modo a esclarecer a questão da possessão erótica como figuração do gesto de leitura.

PALAVRAS-CHAVE: António Franco Alexandre; erotismo; mutismo.

\section{ABSTRACT}

The work of the portuguese poet António Franco Alexandre has been read in various ways. Nevertheless, the interest in receiving is a very recurrent topic. The present paper intends to discuss about how the eroticism is linked with the António Franco Alexandre's poetry and how the Idea of mutism is associated with this anlysis, elucidating the erotic possession issue as an image of the act of reading.

KEYWORD: António Franco Alexandre; eroticism; mutism. 
A leitura é incerta. Tenho pensado nisto muitas vezes. Por virtude de uma leitura específica o tenho ainda mais. E então continuamente recomeço tendo em vista lapidá-la, traçar um recorte menos impreciso, se porventura acreditasse assim ser possível. Estas circunstâncias obrigam-me a afirmar o que, certamente, a ocasião censuraria, entretanto, o digo como um gesto sincero e de grande coragem: tenho medo de António Franco Alexandre. Não me meto com este homem e seus versos. Reafirmo: um medo genuíno (ingênuo?) de suas palavras e do rumor incessante que elas segredam. Mas assim encontrei a minha maneira mais justa de enfrentá-lo: "Quem és tu? Que esse estupendo / corpo, certo, me tem maravilhado!" (Lus., V, 49, 3-4). Corpo poético vasto e de precisa organicidade. Não me meto com este monstro. Contudo, rumo já em sua direção a contornar-lhe, pois é na língua de $\mathrm{AFA}^{1}$ que se procura falar neste ensaio.

A vida é um excesso, está evidente. Esta breve assertiva não é pura divagação deslocada de sentido para quem a poesia é afirmação do mundo e da linguagem em um único gesto. Observe que o poeta, cuja produção vem à tona em finais da década de 60 e início dos 70, é destes que nos fazem crer que a vida é mesmo uma equação em desequilíbrio. "Há felizmente o estilo." (HELDER, 2010, p. 11) A lição muito bem apreendida em Herberto Helder (ou em Mallarmé) confirma a premissa da linguagem como princípio organizador do pensamento. Assim afirma em texto da década de 80 sobre a poesia de Gastão Cruz: "Escrever é pensar: o poema pensa." (ALEXANDRE, 1984, p. 65). Contudo, o estilo, apreensão singular da realidade por meio de uma unidade de significação, só pode conceber a totalidade de determinada experiência como uma abstração, de modo que um olhar para o mundo é sempre uma fissura, um corte. A vida em sua plenitude não cabe nos limites estreitos das palavras estreitas, logo, a poesia que se quer próxima à realidade não poderia deixar de estabelecer laços firmes com o desmedido, o aleatório e, por isso mesmo, com o inominável, o que, por outro lado, nos faria cogitar que a linguagem poética está mais afinada à vesânia que à razão.

Enfim, este trabalho busca, justamente, empreender uma leitura da obra alexandrina, tendo em vista seu fazer literário como expressão erótico-lírica em confrontamento com a desrazão do mundo. Há poesia toda vez que a palavra toca a vida, e, dentro da vida, resta apenas um pacto com o inarticulável. Engana-se a linguagem prosaica na hipótese de que entra numa maior consonância com o objeto significado, posto que sua principal função reduz-se à praticidade da comunicação. A princípio, a arte (que seja a arte das palavras) não pretende comunicar, antes joga com os sentidos, e neste jogo procura o ritmo que se afine aos sentidos do receptor, proporcionando um espaço de interlocução em que ela efetivamente vem à tona. 
O rigor da poesia de que nos fala AFA em seu artigo diz respeito, talvez, a uma postura severamente ética de compreensão dos laços íntimos urdidos entre significação e objeto significado, sendo a conformação deste gesto um ininterrupto assumir-se em desconhecimento perante a exuberância da vida em movimento. Não que a busca pelo conhecimento mostre-se como atividade inútil (veja bem, o poema pensa); neste caso, é curioso observar como para o poeta interessa-lhe, sobretudo, a noção de sabedoria, a recuperação da experiência por meio do erotismo que, enfim, ultrapassa a discursivização. Ou ainda, a imagem do sonho ou devaneio irmanada ao fazer poético articula-se à ideia de como o poeta concebe sua obra, seja aquela a partir da relação dialética entre o real e a representação, em que se estabelece uma interpenetração das duas instâncias no texto. Assim, sem opor contraditoriamente o mundo e a linguagem, o poeta envereda numa arguta problematização da precariedade dos corpos em questão: o humano, frágil e mortal, e o linguístico, nas tensões de erigir a palavra como instrumental poético.

Para tanto, as obras Duende (2002) e Aracne (2004), gêmeas, a meu ver, traçam um itinerário interessante para esta discussão, trazendo à baila um repertório crítico que se pretende nos limites de tal experiência com a linguagem. Estas mesmas são postas em diálogo neste ensaio contribuindo com suas agudas perspectivas acerca do labor literário como problematização dos desníveis provocados pelo choque entre representação e realidade. Valha à custa de exemplo os primeiros versos de Duende:

Fosses tu deus, seria eu santo

alimentado a areia e gafanhotos, sem cessar meditando o único nome que o horizonte não contém.

Sonho que acordo dentro do meu sonho para o saber mais certo e mais real; como o místico leio nas entranhas da ausência a tua sombra desenhada.

(ALEXANDRE, 2002, p. 9)

A interessante construção em mise en abyme do sonho dentro do sonho, ou do sonho lúcido posto que o eu lírico se assume em vigília, compreende um mergulho ao interior do verbo, de modo que a representação, problematizada em sua própria relação íntima com a realidade, é explorada num radical exercício metalinguístico. De certa forma, uma elaboração inversa de tal problemática está expressa em Aracne, naqueles versos em que o aranhiço enamorado afirma que poderia "desenhar figuras, tão reais/ que nelas revelasse/ a verdade maior da fantasia." (ALEXANDRE, 2004, p. 15). O que se pode depreender destas assertivas é, justamente, aquilo que AFA assinala como o processo criativo que, num só movimento, partilha do real e da linguagem, ambos investindo na prática inteligente de compreensão do mundo, porque reconhecidamente interdependentes. 
Ainda o instigante desejo de religação, que quase o aproxima de uma teomania ("Fosses tu deus, seria eu santo"), encontra seu espelhamento na revelação de uma verdade maior, entretanto, verdade esta em face da incessante meditação do "único nome / que o horizonte deserto não contém.” À maneira de uma exercida prática ascética de depuração da palavra poética a qual, enfim, revelasse uma experiência singular da vida em toda sua complexidade, o eu lírico em questão, nos versos de Duende, defronta-se com o vazio. Pondo em questão uma tradição religiosa judaico-cristã essencialmente maniqueísta, a ascese encerrada nos versos de AFA encara o pavor que o nada aflige ao espírito humano como condição imprescindível de constante reavaliação de uma ética pautada no movimento - movimento este que funda suas engrenagens no erotismo. Ao aproximar esta ética à natureza humana, afirma-se uma ascese por meio da carne, o que deve admitir a falta como predisposição do desejo e determina um pacto com aquilo que Marilena Chaui, em ensaio Sobre o medo, designa como o mal.

Assim, o mal há de ser o não-ser. Pura privação e negação, o diabo é essa paradoxal não-entidade que só vem ao ser pela mediação de outrem, carecendo que alguém lhe faça a doação de si para que venha à existência (...). (CHAUÍ, 1987, pp. 40-41)

Ora, nestes termos, nada mais afim à possessão diabólica que a possessão erótica. Compete a este trabalho, todavia, demarcar os rastros da prática da leitura como este gesto de possessão, em que o leitor penetra nos vazios do texto e os sentidos nascem deste instante de suspensão em que há uma confluência entre corpos: "Fica dentro de mim, como se fosse/ eterno o movimento do teu corpo,/ e na carne rasgada ainda pudesse/ a noite escura iluminar-te o rosto." (ALEXANDRE, 2002, p. 11). A imagem visceral construída pelo poeta coaduna-se a este espaço oco, ocupando, entretanto, uma nova geografia, sempre em diferença, a partir do encontro erótico e proporcionando, por meio da interlocução, a possibilidade de uma metamorfose, numa mesma dicção do Transforma-se o amador na cousa amada camoniano. O não-ser referido por Chaui ilustra, também, a propriedade inominável da experiência erótica quando em seu fulgor provoca certo estado de afasia, tal qual Luis Miguel Nava diagnostica na leitura da obra de AFA (NAVA apud MARTELO, 2009, p. 269). Em seu limite (a poesia), a palavra (co)incide sobre seu objeto, referido de tal forma que pode assemelhar-se ao silêncio - efeito similar àquele provocado no culto sacrificial em que se atravessa a descontinuidade da vida, devolvendo o ser à sua continuidade ou ao último reduto do Um: a morte.

\section{SOBRE A POSSESSÃO}

Quando Georges Bataille afirma que o erotismo "é a aprovação da vida até na morte" (BATAILLE, 2004, p. 19), vibram, em tal assertiva, estas mesmas noções de continuidade e descontinuidade que fazem da experiência erótica um exercício de metamorfose. $\mathrm{O}$ objeto deste trabalho funda-se sobre uma leitura da obra alexandrina, a qual, a sua maneira, compreende 
a linguagem em sua relação de troca com um interlocutor, portanto, o lugar privilegiado da recepção no processo de construção de sentido. Nestes mesmos termos, a observância das severas implicações, no que diz respeito a esta subjetividade a se criar na obra alexandrina, põe em discussão o próprio papel da elocução. A incerteza, os estados de dúvida, ou mesmo os efeitos de indecidibilidade provocados pela poesia de AFA desnorteiam aquele que se aventura nesta leitura enquanto o devoram. O poeta faz falar em seus versos o abismo que separa a obra de seu leitor, pois sabe que neste ponto são gerados os sentidos, ou ainda, é neste instante de suspensão em que inclinamos nosso rosto sobre a página escrita que a experiência de leitura é imageticamente recriada como experiência erótico-lírica.

A abertura à continuidade provocada pelo encontro erótico de duas potências descontínuas compreende aquela morte transitiva de que se trata a transformação dos corpos amantes. E, sim, um discurso amoroso embala este movimento, o que desloca a questão para o campo da linguagem (o que se está a comentar até então). A descontinuidade, notada por Bataille entre os seres reprodutores e reproduzidos na atividade sexual, assim como ambos entre si, é problematizada por AFA na encenação que faz de sua poesia. Assim, o abismo que aqui se refere é, também, este traçado entre obra e leitor, ou mesmo entre as palavras e as coisas. Não que haja uma mesma relação distintiva entre as ordens comparativas, mas o que se quer realçar é a observação de que no seio da linguagem, assim como no encontro erótico, persiste o signo da diferença. Nesta trilha, a poesia de AFA dá espaço para que cada palavra, cada gesto, cada encontro desfrute da fascinação de um acontecimento singular. Por outro lado:

Suportamos mal a situação que nos sujeita à individualidade do acaso, à individualidade perecível que somos. Ao mesmo tempo que temos o desejo angustiado da duração deste perecível, temos a obsessão por uma continuidade primeira, que nos religa geralmente ao ser. (BATAILLE, 2004, p. 26)

Está em confronto a vivência do perecível e do perene. Os amantes sonham com este tempo fora do tempo, o momento único (e eterno [?] em sua memória) em que se entregam à pessoa amada, instante oscilante entre aquele que é e o que está a se tornar. "Mas eu, quando me cubro do teu rosto/ e sou somente de água e fogo feito,/ melhor ainda te conheço e quero,/ e nada no teu corpo me é alheio:/ em cada grão de pele te desejo,/ em cada ruga leio o meu destino." (ALEXANDRE, 2002, p. 13). A lógica do desejo implicada na poética alexandrina assume, também, a conformidade de uma experiência de leitura em embate com a tensão entre uma morte transitiva e uma morte intransitiva: a ruga lida no destino do eu lírico constata a inexorabilidade da passagem do tempo como contraponto da unidade em deslocamento prometida pela experiência erótica, a qual reconhece as suas feições na ascese lírica de um incansável teólogo quando ao provar “como é eterno agora este só dia." (ALEXANDRE, 2002, p 17) 
O enamorado é, sobretudo, um ser em devir. Deste modo, se, por um lado, a continuidade no corpo do ser amado é uma saída para o sofrimento provocado pelo isolamento da descontinuidade, por outro, o gozo experienciado neste momento singular deve lidar com a angústia e a delícia da despossessão: com o fato de que o encontro único engendrado por sua subjetividade na confluência com outra é a experiência de um outro de si mesmo.

A partir desta reflexão, a ideia de que o amor cria os próprios obstáculos àquele que procura conhecê-lo se mostra como o incontornável paradoxo por meio do qual se constitui e cuja forma exemplar, em literatura portuguesa, Camões oferece em seu célebre soneto Amor é um fogo que arde sem se ver. Interessa, neste caso, observar que o poeta quinhentista já concebe a experiência amorosa como sujeito moderno, atribuindo, assim, ao amor o peso de um modo de sentir único e intransferível, na medida em que se aprofunda a consciência de tal autonomia.

O projeto alexandrino de uma ética da movência se entrança nestas malhas, este que, ao se chocar com a lucidez de uma consciência que reconhece, no acaso infeliz, a sua existência descontínua, deslocada e perecível, não se deixa ser tomado por marco funerário e, continuamente, se lança em direção ao outro, em meio aos desníveis da interlocução: "Mas se vou transformar-me, não aspiro/ à condição de marco funerário/ ou ténue monumento de mim mesmo;" (ALEXANDRE, 2004, p. 46). Assim, não é de se afirmar que o amador não se transforma na coisa amada ou que a busca pelo conhecimento é em vão. Não é este o caso. Pois é nestes intervalos deveras desconcertados que leitor e obra desfrutam de seu estar no mundo em constante mudança. Um novo olhar sobre o texto de AFA permitirá outras leituras e tornamo-nos, nós leitores, (talvez) mais experientes a cada uma delas.

O problema da leitura novamente vem à tona. Joaquim Manuel Magalhães, em ensaio acerca da poesia alexandrina, afirma:

As palavras com que nos faz partilhar o seu enfrentamento de mundo, a densidade emocional com que nos lembra a exaltante mágoa do encontro dos corpos, a encenação de que nos faz testemunhas e participantes, fazem da sua obra poética um dos exemplares lugares trágicos do esquecimento a que a nossa recente poesia se encontra votada. (MAGALHÃES, 1981, p. 250)

O fragmento de Joaquim Manuel Magalhães, retirado de texto intitulado apenas António Franco Alexandre, o qual consta em Os dois crepúsculos: Sobre poesia portuguesa actual e outras crónicas, ressalta dois aspectos que são, evidentemente, de extrema importância para a leitura pretendida neste trabalho. A ideia de partilha como estruturadora de um duplo movimento de recolha e dispersão, o que, de certa forma, fora também apontado por Rosa Maria Martelo na imagem da onda ao se referir ao fazer poético 
de $\mathrm{AFA}^{2}$. E, por fim, a tensão entre memória e esquecimento a que toda poesia está sujeita e que em sua obra também é patente. Numa visão bem heraclitiana, o constante e inapreensível fluxo do tempo não se permite dar a conhecer senão numa relação referencial de permanência e impermanência; deste modo, a ação no mundo, para esta poesia, consubstancia-se ao dever essencialmente transformador da arte. Fatal transformação...

\section{SOBRE O SILÊNCIO}

Leio os versos de Duende:

Fala-me agora, que não tenho boca e sou na tua pele mero ouvido, diz-me palavras soltas sem sentido ou pede-me por graça o consentido. Olha-me só para que veja como tão claro e fundo olhar me tem mantido na solidão sem nome deste pranto; ou escreve em mim com hálito de lume para que seja eu a enrodilhada chama que se esquece de si e sonha o fumo. (ALEXANDRE, 2002, p. 10, grifo nosso)

A escrita no (do) ser amado busca uma confluência por meio do movimento erótico, o que permite um interessante jogo de espelhamento entre os corpos em questão, de modo que as formas reflexivas dos verbos utilizados nestes versos permitem tal possibilidade de leitura em que amador e amado unem-se num único ser ("nada no teu corpo me é alheio"). Desta união, nutrem-se, afinal, os corpos amantes ao instituir uma possessão erótico-lírica, desestabilizando, então, a hipótese de conformação desta experiência junto à vida por meio de um sistema de signos: “... todos sentimos o que é a poesia. Ela nos funda, mas não sabemos falar dela." (BATAILLE, 2004, p. 40) Então também não saberemos falar da vida? Ou porventura não falamos senão de outra coisa?

Num momento limítrofe, a palavra proferida é a vivência fundamental da metamorfose, a violência que arranca o ser da descontinuidade e o desnuda diante da morte; afinal, o uso da linguagem, mais especificamente da linguagem poética, é uma experiência de morte. Não sabe o leitor que também ele morre aos poucos ao desfolhar as páginas de um breve livro.

O que vem dito até então corresponde à ideia de que o conhecimento erótico é um lançar-se ao impossível, um ininterrupto poder-ser em diferença: é um salto ao desconhecido. Como afirma Bataille, a continuidade provocada pelo movimento erótico corresponde a um segredo, o que leva a crer que este não é conhecível, no máximo pode ser experimentado. De certa forma, a poesia de AFA se afina com esta perspectiva quando se 
traz à discussão, por exemplo, a importância do mutismo em sua obra ou mesmo de um não-dizer que a sonoridade de seus versos suscita: "no sussurro sem fios, que mal entendo, / colho o meu mel pequeno, e sou feliz." (ALEXANDRE, 2004, p. 8) Afina-se justamente a estas vozes pequenas, na medida de sua discrição. No entanto, assaz poderosas.

"A poesia leva ao mesmo ponto que cada forma de erotismo, à indistinção, à confusão dos objetos distintos. Ela nos leva à eternidade, ela nos leva à morte, à continuidade: a poesia é a eternidade." (BATAILLE, 2004, p. 40). Ao ler este comentário de Bataille sobre a natureza da poesia e seus laços com a experiência erótica, compreendemos melhor o sentido do que se deseja assinalar com o silêncio nos versos de AFA. O silêncio, enquanto estado absoluto, é pura ausência (de som), e, como o que é próprio do que é absoluto, causa-nos medo. Se aproximada tal perspectiva à presença - ou sinal antecipador - da morte, torna-se mais clara a imagem pretendida. O que interessa, acima de tudo, é assimilar esta ideia ao movimento criativo. Disse-se, ao início deste ensaio, que a vida é um excesso. Conforme; e a discussão em torno da palavra poética como representação (em falta) do mundo coaduna-se a esta problemática, de maneira que aproxima seus laços urdidos com o real ao confrontar os desníveis desta relação. Ora, o gesto criativo preocupa-se, justamente, em habitar estes espaços de confluência. No dizer do próprio AFA: "Nem não se sabe que malabarismo verbal indiferente, nem mítica expansão de sensibilidades mal sofridas, mas afirmação do mundo e da linguagem, num gesto só, viver, escrever, apreender, criar, indissolúveis." (ALEXANDRE, 1984, pp. 65-66). O que se procura discutir, a partir do fragmento destacado, é como esta confluência entre o real e a palavra tem importante papel no que diz respeito à fundamentação de uma ética na poesia de AFA. O quadro ganha seu fundo, ainda, observada a interlocução como o motor que engendra a força dos sentidos em dada obra.

Leitor, ou crítico, terão antes de mais que entrar no espaço de pensamento vivo, no instrumento e lugar de conhecimento que o poema é, que discutir a lição de real que o poema é, sob pena de se ficarem pela nulidade da impressão toscamente "subjetiva". (ALEXANDRE, 1984, p. 66)

No jogo lírico-amoroso construído por AFA em sua poesia, ou no espaço de pensamento que o poema é, a vida proclamada em versos é deveras similar àquela empreendida por Bataille na experiência erótica, a qual é afirmada mesmo na morte. Afirmada na morte porque no instante limite de transformação, num espaço de fronteira entre os corpos, em que o encontro com o desconhecido é a presentificação do inarticulável. "Quero ser eu, um dia, aquela voz/ que te faz ficar mudo e transparente/ ainda quando diz os tolos versos / em que o amor se diz habitualmente." (ALEXANDRE, 2002, p. 28). Assim, os corpos em conflito ordenam um pacto (diabólico?), o retorno à continuidade. Como em Duende é explicitado, 
a construção de sentido é uma relação entre partes consensuais, estando assente o pensamento que, vivo, procura a forma a atribuir à experiência, em constante transmutação - sempre um mistério: “... diz-me palavras soltas sem sentido / ou pede-me por graça o consentido." (ALEXANDRE, 2002, p. 10). Pois então, sem ou com sentido, no intercâmbio entre as duas instâncias, o pensamento vivo reivindicado pelo poeta é a assimilação do contradiscurso que exercita em sua poesia quando "se esquece de si e sonha o fumo", ou seja, inter-relaciona as variáveis de sua proposição poética e as lança ao outro, ao leitor que fará delas um outro real.

$$
\begin{aligned}
& \text { Se me prendo ao teu rumor ausente } \\
& \text { não é que me consuma numa imagem } \\
& \text { ou deseje real o imaginado; } \\
& \text { é por outro real em ti presente. } \\
& \text { (ALEXANDRE, 2002, p. 23) }
\end{aligned}
$$

O rumor ausente, ou a palavra silêncio, é o espaço oco, côncavo, o útero onde se geram os sentidos. Defrontar-se com este vazio - a teia sem enredo de Aracne - é a empreitada que a poesia de AFA se impõe. "A teia sem enredo é a minha ideia fixa, / puro cristal, como os da neve, abstracto, / tão claro como o mero abecedário / onde as palavras falam, sem barulho" (ALEXANDRE, 2004, p. 16). O apuro da construção linguística vem suprir a palavra em falta e, no entanto, o que encontra ao cabo de tal experiência, longe de uma possível plenitude significativa imaginada, é seu vazio. E nada irá salvar o poeta desta angústia, pois o que procura ocupa a distância insuperável entre o que é e o que poderia ter sido: o intervalo "onde as palavras falam, sem barulho”. Rosa Maria Martelo nos esclarece a questão:

\begin{abstract}
À desconfiança que os poemas de António Franco Alexandre repetidamente deixam transparecer relativamente à poesia, junta-se o facto de esses poemas assumidamente produzirem um discurso que diz descrer do discurso e que, por isso, procuraria mover-se nos intervalos da escrita, tentando determinar algo que passa entre as palavras e escapa à lexicalização, ou mesmo à discursivização. (MARTELO, 2009, p. 266)
\end{abstract}

Entregar-se ao vazio, possuí-lo e deixar-se ser possuído, lapidar o verbo bruto: AFA traça tal (der)rota em direção ao desconhecido, a curva descendente que também nos ensina os movimentos de uma nova queda. Afinal, dentre as vozes ouvidas em seus versos, aquela que se ouve com maior insistência é a mesma ouvida no intervalo dos discursos e o estado de dúvida em que é deixado o leitor após o contato com sua obra, seu abandono derradeiro.

Ou talvez uma justa chave de interpretação. Se pela incerteza se compõe seu texto, com eles a leitura se conjuga. 


\section{REFERÊNCIAS BIBLIOGRÁFICAS:}

ALEXANDRE, António Franco. Aracne. Lisboa: Assírio \& Alvim, 2004. . Duende. Lisboa: Assírio \& Alvim, 2002.

. Gastão Cruz: Poesia 1961-1981. In. Revista Colóquio/Letras.

Notas e Comentários, n 81, Set. 1984, p. 65-68.

BATAILlE, Georges. O erotismo. Tradução de Cláudia Fares. São Paulo: Arx, 2004.

CAMÕES, Luis de. Os Lusíadas. Edição organizada por Emanuel Paulo Ramos. Porto: Porto editora, 1978.

- Rimas. Texto estabelecido e prefaciado por Álvaro Júlio da Costa Pimpão. Coimbra: Atlântida Editora, 1973.

CHAUÍ, Marilena. Sobre o medo. In. Os sentidos da paixão. NOVAES, Adauto (org.). São Paulo: Companhia das Letras, 1987.

HELDER, Herberto. Estilo. In. Os passos em volta. 2. ed. Rio de Janeiro: Azougue, 2010.

MAGALHÃES, Joaquim Manuel. António Franco Alexandre. In. Os dois crepúsculos: Sobre poesia portuguesa actual e outras crônicas. A regra do jogo, 1981. p. 245-250.

MARTELO, Rosa Maria. O “especialista em sublimação" e os usos da linguagem (acerca da poesia de António Franco Alexandre). In. Cadernos de Literatura Comparada 20 - Artes da Perversão. Porto: Instituto de Literatura Comparada Margarida Losa da faculdade de Letras da Universidade do Porto. Junho de 2009. p. 260-283.

(Recebido para publicação em 14/01/2012,

Aprovado em 01/02/2012)

\section{NOTAS}

1 A partir de agora, o poeta será designado como AFA.

2 Citação a Rosa Maria Martelo (MARTELO, 2009, p. 270). A ensaísta aponta os efeitos de indecidibilidade nos usos da linguagem de AFA, espécie de movimento de fluxo e refluxo da palavra poética, a qual é empregada como ruína para uma nova construção que consequentemente se implodirá. Em resumo, um discurso fundamentado contra si próprio. 